\title{
Protein profiles of hatchery egg shell membrane
}

\author{
N. C. Rath ${ }^{1 *}$, R. Liyanage ${ }^{2}$, S. K. Makkar ${ }^{3}$ and J. O. Lay Jr. ${ }^{2}$
}

\begin{abstract}
Background: Eggshells which consist largely of calcareous outer shell and shell membranes, constitute a significant part of poultry hatchery waste. The shell membranes (ESM) not only contain proteins that originate from egg whites but also from the developing embryos and different contaminants of microbial and environmental origins. As feed supplements, during post hatch growth, the hatchery egg shell membranes (HESM) have shown potential for imparting resistance of chickens to endotoxin stress and exert positive health effects. Considering that these effects are mediated by the bioactive proteins and peptides present in the membrane, the objective of the study was to identify the protein profiles of hatchery eggshell membranes (HESM).

Methods: Hatchery egg shell membranes were extracted with acidified methanol and a guanidine hydrochloride buffer then subjected to reduction/alkylation, and trypsin digestion. The methanol extract was additionally analyzed by matrix assisted laser desorption ionization-time of flight mass spectrometry (MALDI-TOF-MS). The tryptic digests were analyzed by liquid chromatography and tandem mass spectrometry (LC-MS-MS) to identify the proteins.

Results: Our results showed the presence of several proteins that are inherent and abundant in egg white such as, ovalbumin, ovotransferrin, ovocleidin-116, and lysozyme, and several proteins associated with cytoskeletal, cell signaling, antimicrobial, and catalytic functions involving carbohydrate, nucleic acid, and protein metabolisms. There were some blood derived proteins most likely originating from the embryos and several other proteins identified with different aerobic, anaerobic, gram positive, gram negative, soil, and marine bacterial species some commensals and others zoonotic.
\end{abstract}

Conclusion: The variety of bioactive proteins, particularly the cell signaling and enzymatic proteins along with the diverse microbial proteins, make the HESM suitable for nutritional and biological application to improve post hatch immunity of poultry.

Keywords: Hatchery egg shell membrane, Proteins, Mass spectrometry

\section{Background}

Egg shells that constitute a significant part of poultry hatchery waste, comprise largely of calcium carbonate crusts and underlying shell membranes laced with proteins originating from egg whites as well as contaminants of microbial and environmental origins [1]. The shell membranes have been considered for various engineering, agricultural, and biomedical applications, spurring many studies of their biochemical compositions [2-9]. Most such studies however, have used membranes harvested from fresh eggs and shown to contain proteins

\footnotetext{
* Correspondence: Narayan.rath@ars.usda.gov

${ }^{1}$ USDA/Agricultural Research Service, Poultry Production and Product Safety Research Unit, Fayetteville, AR 72701, USA

Full list of author information is available at the end of the article
}

and peptides of structural, antimicrobial, cell regulatory, and stress protective categories which likely contribute to their some of their health beneficial and therapeutic effects [2, 10-19]. Recently, we reported that the hatchery shell membranes (HESM), used as nutritional supplement, in post hatch chicks, promote growth, show protection against bacterial lipopolysaccharide (LPS) induced inflammatory response and diminish stress markers such as plasma levels of corticosterone [20]. Presuming that these effects could be mediated through the bioactive proteins present in the HESM, we were interested to analyze the proteomic composition of HESM that has never been investigated. Besides, the protein population of HESM can be qualitatively different from the fresh 
egg shell membrane because the embryo development not only induce dynamic changes in egg proteome [21, 22] but also, alter the membrane structure to facilitate the hatching process. Hence, the current study was conducted utilizing the HESM that were dried at room temperature in a chemical hood without additional cleanup for 2 month period in the room temperature.

\section{Methods}

\section{Chemicals and reagents}

The reagents and devices such as $\mathrm{C} 18 \mathrm{Nu}$ tips (Glysci.com), Spectra/Por membranes (Spectrumlabs.com), bicinchoninic acid (BCA) protein assay kit, Pierce $\mathrm{C} 18$ spin columns, MS grade trypsin (Fisher Scientific.com), peptide and protein calibration standards $(\mathrm{m} / \mathrm{z} 500-16000$, Bruker Daltonics, Bremen, Germany), and 2-iodoacetamide (IAA) (MP Biomedical, OH) were purchased from their respective vendors. Most other chemicals and supplies including 1, 4-dithiothreitol (DTT), 2, 5-dihydroxybenzoic acid (DHB), were purchased from Sigma Aldrich (St. Louis, MO).

\section{HESM preparation}

Empty eggshells were obtained from the University of Arkansas poultry hatcheries, dried at room temperature under the hood for 2 months, the membranes separated manually then ground to coarse powder using an IKA mill (Cole Palmer). Duplicate samples of membrane powder from two separate preparations, each made from $>50$ eggs, were extracted (a) with $0.1 \%$ acetic acidified $70 \%$ methanol for soluble proteins, peptides, and their degradation products, and (b) with $4 \mathrm{M}$ guanidine hydrochloride $(\mathrm{GuHCl})$ containing $20 \mathrm{mM}$ EDTA, and $50 \mathrm{mM} \mathrm{Na}$-acetate, $\mathrm{pH} 5.8$ for all soluble proteins $[17,23]$. The membrane powder were extracted with 20 volumes of respective solutions overnight at $4{ }^{\circ} \mathrm{C}$ by constant stirring then centrifuged at 20,000 g for $15 \mathrm{~min}$ and the supernatants containing all soluble factors were dialyzed against excess volumes of $50 \mathrm{mM}$ ammonium bicarbonate with three successive changes using $1000 \mathrm{Da}$ Spectra/Por dialysis membranes. The solutions containing approximately $20 \mu \mathrm{g}$ of protein from each extract, measured by BCA protein assay, were reduced with $10 \mathrm{mM}$ dithiothreitol (DTT) for $1 \mathrm{~h}$ at $60{ }^{\circ} \mathrm{C}$ and alkylated with $40 \mathrm{mM}$ iodoacetamide (IAA) then digested with $0.4 \mu \mathrm{g}$ trypsin for $48 \mathrm{~h}$ at $37{ }^{\circ} \mathrm{C}[23,24]$. The tryptic digests were desalted using Pierce $\mathrm{C} 18$ spin columns according to the manufacturer suggested protocol prior to liquid chromatography-tandem mass spectrometry (LC-MS/MS).

\section{LC-MS/MS analysis}

Following desalting with $\mathrm{C} 18$ columns, the peptides were eluted, dried and re-suspended in $0.1 \%$ formic acid (FA) then subjected to LC-MS/MS using an Agilent 1200 series micro flow HPLC coupled to a Bruker Amazon-SL quadrupole ion trap mass spectrometer, and a captive spray ionization source. Tryptic peptides were separated at a solvent flow rate of $1.6 \mu \mathrm{L} / \mathrm{min}$ with 0 to $40 \%$ gradients of $0.1 \%$ FA (solvent A) and acetonitrile (ACN) in $0.1 \%$ FA (solvent B) over a period of 300 min each using a $\mathrm{C}_{18}(150 \times 0.1 \mathrm{~mm}, 3.5 \mu \mathrm{m}$ particle size, $300 \AA$ A pore size, Zorbax SB) capillary column. The captive electrospray source was operated in a positive ion mode with a dry gas temperature of $150{ }^{\circ} \mathrm{C}$, dry nitrogen flow $3 \mathrm{~L} /$ minute, and capillary voltage of $1500 \mathrm{~V}$. The data were acquired in the auto MS (n) mode with optimized trapping condition for the ions at $m / z 1000$. MS scans were performed in the enhanced scanning mode $(8100 \mathrm{~m} / z /$ second $)$, while the collision-induced dissociation or the MS/MS fragmentation scans performed automatically for top ten precursor ions for $1 \mathrm{~min}$ each in the UltraScan mode $(32,500 \mathrm{~m} / \mathrm{z} / \mathrm{second})$. The samples were run three times as technical repeats.

\section{MALDI-TOF analysis}

For direct matrix assisted laser desorption ionizationtime of flight mass spectrometry (MALDI-TOF-MS), aliquots of methanol extracts were subjected to reduction/ alkylation using DTT and iodoacetamide (IAA) as described previously [25] or mock treated omitting DTT from the reaction for respective controls then spotted on a MALDI target plate mixing at 1:1 ratio with two dihydroxybenzoic acid. In all cases, samples were first subjected C18 nu tip cleaning up process using manufacturer recommended protocol before spotting on the MALDI target plate. The mass spectra were acquired with a Bruker Ultraflex II MALDI-TOF mass spectrometer (Bruker Daltonics GMBH, Bremen, Germany) operated in the positive-ion reflectron mode with the TOF analyzer calibrated with Bruker peptide standard II. Accurate mono isotopic protonated, intact peptide, masses were determined by MALDI-TOF-MS using combinations of external and internal calibration procedures, spotting the samples with equal volumes of $\alpha$ cyano-4-hydroxycinnamic acid matrix, prepared in $0.1 \%$ $\mathrm{FA}$, and 50:50 water/ACN. The MALDI-TOF-MS data were processed and some selective peaks were fragmented using LIFT-TOF/TOF MS to obtain their identities [17].

\section{Data analysis}

Peaks were picked from the LC-MS/MS chromatogram using instrument's default settings and the mzML files created using Bruker Data Analysis 4.0 software. The mzML files created as such were used in Bruker ProteinScape 3.1 server with MASCOT data base search tool to perform MS/MS data search against the UniProt Gallus and NCBI bacterial data bases to identify the proteins. 
All proteins were identified with a 95\% confidence limit and $<1 \%$ false discovery rate with at least one unique peptide. The parent ion mass- and fragment ion mass tolerance were both, set at 0.6 Da with cysteine carbamidomethylation and methionine oxidation as fixed and variable modifications. MASCOT.dat data base search files and.mzML raw data files were then exported into Skyline v3.1 software (http://proteome.gs.washington.edu/ software/Skyline) [26, 27] to further refine the tryptic peptide identification based on their relative hydrophobicity and retention time correlations. Protein identities were also refined based on the uniqueness of the identified tryptic peptides by comparing them against respective background proteomes (either UniProt Gallus or the NCBI Bacteria data bases). The MALDI-TOF-MS data were processed using Bruker Flex Analysis 3.3 and Bruker BioTools 3.1 software. Peptides were identified by MASCOT MS/MS ion search tool with a peptide mass tolerance of $200 \mathrm{ppm}$ and MS/MS ion tolerance of $0.6 \mathrm{Da}$. Functional annotation and classification of the proteins identified by LC-MS/MS with two or more unique peptides were performed using gene ontology (GO) based PANTHER classification system (http://www.pantherdb.org) [28] and proteins refined by Skyline from both guanidine and methanol extracts. Also, the same proteins were used in STRING functional protein association networks, version 10 (http://string-db.org) [29], under a high confidence setting to identify protein co-occurrence and possible functional relations.

\section{Results}

Table 1 shows the list of 41 proteins identified in the methanol extract using LC-MS/MS analyses and the Additional file 1: Table S1 shows the identities of 167 proteins in the $\mathrm{GuHCl}$ extracts of which 11 were common in both extracts which occur in egg white such as ovalbumin, ovomucoid, ovocleidin-116, and lysozyme (Table 1, names underlined). Several identified proteins on the basis of a single peptide were considered tentative although they were identified repeatedly in replicate samples and by Skyline retention time correlation refinements. These identifications were largely occurred in methanol extract which may relate to degraded proteins. There were 12 uncharacterized proteins including one in methanol extract. Several structural proteins that included collagens, keratin, proteoglycans (lumican, decorin) were identified in the HESM. Different keratins that included both cytoskeletal type 1 and non-cytoskeletal were abundant in HESM. Many cytoskeletal and their cognate proteins such as actin, vinculin, gelsolin, tubulin, vimentin, thymosin $\beta 4$, and some blood associated proteins (annexins, hemoglobin, epsilon globin, and serum albumin) predominated in the guanidine extract. Cell signaling and enzyme proteins largely, associated with energy, protein, and nucleic acid metabolisms, and several antimicrobial proteins that included ovotransferrin, lysozyme, ovocleidin-116, ovocalyxin-36, keratin peptides, and gallinacin 9 and 10, were present. Some of the other proteins that secured high scores were embryonic and development associated proteins such as zona pellucida sperm binding proteins, elongation factors, and histone cluster proteins. Functional annotation with PANTHER using combined protein IDs from both extracts (methanol and guanidine) and GOslim molecular function sorted the proteins into six major categories using 98 gene products with the binding, structural, and catalytic proteins topping the list (Fig. 1). A classification of protein functionality showed two dominant associations, one, with nucleic acid binding and the other with cytoskeletal function, followed by structural, transfer/ carrier, and oxidoreductase genre of proteins (Fig. 2). Some proteins uniquely present in methanol extract of HESM, such as gallinacin 9, thymo$\sin \beta 4$, and septin, were not detected in the guanidine $\mathrm{HCl}$ extract. A protein interaction and co-occurrence map, using STRING bioinformatics, showed a major cluster of proteins associated with nuclear and metabolic activities (eg: ribosomal proteins) and two others associated with carbohydrate metabolism and actin/ actincognate function, respectively (Fig. 3). The MALDI-TOF MS of methanol extract showed several peaks of which 2, corresponding to $\mathrm{m} / z 4643$ and 4773 (Fig. 4a), showed mass shifts by $348 \mathrm{Da}$ upon reduction/ alkylation (Fig. 4b), suggestive of carbamidomethylation of three disulfides, whereas, few other peaks such as $m / z 2682,2624,2835$, and 2126 did not show any change. Based on our previous identification in ESM [17], we surmised that the $m / z 4773$ was the mature gallinacin 10 peptide with a corresponding sequence of "DPLFPDTVACRTQGNFCRAGACPPTFTIS GQCHGGLLNCCAKIPAQ" and the $m / z 4643$ was the same peptide with the truncation of glutamine $(\mathrm{Q})$ from the N-terminal. Fragmentation of $\mathrm{m} / z 2682$ peptide by LIFT-MS/MS (Fig. 5) yielded a partial sequence corresponding to "AGGSVPGRPLPNEAL" which upon protein blast (BLASTP) (http://blast.ncbi.nlm.nih.gov/Blast.cgi? PAGE=Proteins), in non-redundant protein data base showed $>90 \%$ identity with one Apicomplexan specific protein associated with Eimeria, a protozoa that causes coccidiosis in poultry. Using NCBI bacteria data base search, the proteins in $\mathrm{GuHCl}$ extract, showed 50 proteins belonging to different species of gram positive, gram negative, aerobic and anaerobic families of bacteria that included Candidatus, Enterococci, Yersinia, and Butyrivibrio, and several phytobacteria (Sphingomonas taxi), Nocardioide (soil bacteria), and a marine bacterium (hyphomonas, marinobacter adhaerens) (Additional file 1: Table S2). Many of these identifications were tentative based on the matches with their respective enzyme proteins with 
Table 1 Proteins identified in methanol extract by LC-MS/MS. Proteins with a single peptide are considered "tentatively identified"

\begin{tabular}{|c|c|c|c|c|c|}
\hline & Accession & Protein & $\mathrm{MW}[\mathrm{kDa}]$ & Scores & \# Peptides \\
\hline 1 & ENSGALP00000036403 & Ovalbumin & 42.9 & 629.9 & 11 \\
\hline 2 & ENSGALP00000005544 & Ovomucoid & 22.6 & 338.1 & 7 \\
\hline 3 & ENSGALP00000017755 & $\underline{\text { Ovocleidin-116 }}$ & 76.8 & 225 & 2 \\
\hline 4 & ENSGALP00000008163 & Orosomucoid 1 (ovoglycoprotein) precursor & 22.3 & 167 & 3 \\
\hline 5 & ENSGALP00000042635 & peptidyl-prolyl cis-trans isomerase FKBP1A & 8.9 & 163.5 & 3 \\
\hline 6 & ENSGALP00000016177 & $\underline{\text { Lysozyme C }}$ & 16.2 & 129.2 & 2 \\
\hline 7 & ENSGALP00000016632 & keratin 8, type II & 42.1 & 119.1 & 2 \\
\hline 8 & ENSGALP00000031725 & SH3 domain binding glutamic acid-rich protein like (SH3BGRL), mRNA & 12.9 & 109.6 & 2 \\
\hline 9 & ENSGALP00000027483 & Ubiquitin-fold modifier 1 & 9 & 102.1 & 1 \\
\hline 10 & ENSGALP00000035930 & Gallinacin-9 & 7.3 & 85.7 & 2 \\
\hline 11 & ENSGALP00000010763 & Ovocalyxin-36 precursor & 58.3 & 83.7 & 1 \\
\hline 12 & ENSGALP00000019758 & $\begin{array}{l}\text { Diazepam binding inhibitor (GABA receptor modulator, } \\
\text { acyl-CoA binding protein) (DBI), mRNA. }\end{array}$ & 9.6 & 69.8 & 2 \\
\hline 13 & ENSGALP00000026846 & Gallinacin-10 & 7.1 & 62.6 & 2 \\
\hline 14 & ENSGALP00000006093 & Keratin, type I cytoskeletal 19 & 46 & 62.3 & 3 \\
\hline 15 & ENSGALP00000009976 & Usher syndrome $1 \mathrm{C}$ & 100.1 & 51.9 & 1 \\
\hline 16 & ENSGALP00000012729 & Uncharacterized protein & 21 & 50.9 & 1 \\
\hline 17 & ENSGALP00000040654 & Thymosin, beta 4 & 5 & 47.8 & 2 \\
\hline 18 & ENSGALP00000043411 & Collagen, type XVI, alpha 1 & 156.6 & 42 & 1 \\
\hline 19 & ENSGALP00000002523 & Signal peptidase complex subunit 1 homolog & 27.2 & 37.9 & 1 \\
\hline 20 & ENSGALP00000013908 & Zinc finger BED domain-containing protein 4 & 132.4 & 37.8 & 2 \\
\hline 21 & ENSGALP00000038912 & 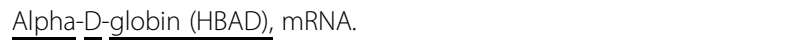 & 15.7 & 37.3 & 1 \\
\hline 22 & ENSGALP00000019988 & Utrophin & 398.6 & 36.5 & 2 \\
\hline 23 & ENSGALP00000000876 & $\underline{\text { Fatty acid-binding protein, heart }}$ & 14.8 & 34.6 & 1 \\
\hline 24 & ENSGALP00000026777 & Nociceptin precursor & 21.4 & 34.4 & 1 \\
\hline 25 & ENSGALP00000026863 & Polycystic kidney and hepatic disease 1 (autosomal recessive) & 440 & 32.7 & 1 \\
\hline 26 & ENSGALP00000018601 & Serine peptidase inhibitor, Kazal type 2 (acrosin-trypsin inhibitor) & 6 & 26.7 & 1 \\
\hline 27 & ENSGALP00000025439 & Probable arginyl-tRNA synthetase, mitochondrial & 65.3 & 25.2 & 1 \\
\hline 28 & ENSGALP00000039913 & Transforming, acidic coiled-coil containing protein 1 & 86.4 & 24.5 & 2 \\
\hline 29 & ENSMGAP00000001722 & elaC ribonuclease Z 2 & 94.2 & 24.2 & 1 \\
\hline 30 & ENSGALP00000031519 & Fibroblast growth factor 2 & 16.2 & 22.8 & 1 \\
\hline 31 & ENSGALP00000039675 & Nuclear receptor coactivator 2 & 44.7 & 21.5 & 1 \\
\hline 32 & ENSGALP00000000325 & WD repeat-containing protein 36 & 98.2 & 21.2 & 1 \\
\hline 33 & ENSGALP00000019412 & Septin 3 & 40 & 20.5 & 1 \\
\hline 34 & ENSGALP00000027541 & High mobility group protein B1 & 24.9 & 20 & 1 \\
\hline 35 & ENSGALP00000014919 & tRNA (adenine-N(1)-)-methyltransferase non-catalytic subunit TRM6 & 54.2 & 19.8 & 1 \\
\hline 36 & ENSGALP00000043133 & Fibrinogen silencer binding protein & 36.4 & 19 & 1 \\
\hline 37 & ENSGALP00000000726 & SH3 domain binding glutamate-rich protein like 3 & 10.5 & 18.8 & 1 \\
\hline 38 & ENSGALP00000038283 & UPF3 regulator of nonsense transcripts homolog B (yeast) & 56.9 & 18.4 & 1 \\
\hline 39 & ENSGALP00000000275 & Mutated in colorectal cancers & 112.6 & 18.3 & 1 \\
\hline 40 & ENSGALP00000038735 & Polyubiquitin-B Ubiquitin & 109.6 & 15.5 & 1 \\
\hline 41 & ENSGALP00000040476 & Neuregulin 2 & 65.5 & 15 & 1 \\
\hline
\end{tabular}

The underlined proteins also occur in guanidine $\mathrm{HCl}$ extract (Additional file 1: Table S1) 


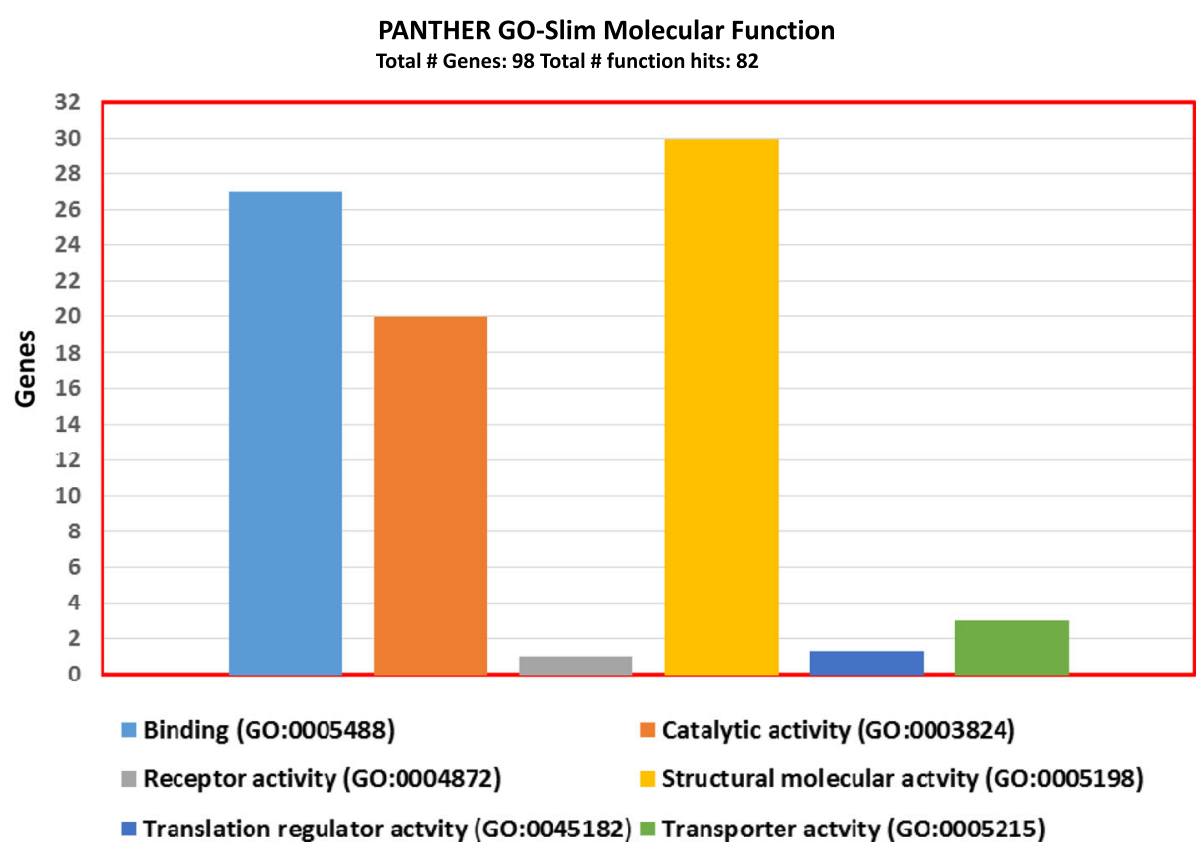

Fig. 1 Molecular function annotation of proteins, identified with two or more unique peptides, using Protein Analysis through Evolutionary Relationships (PANTHER)

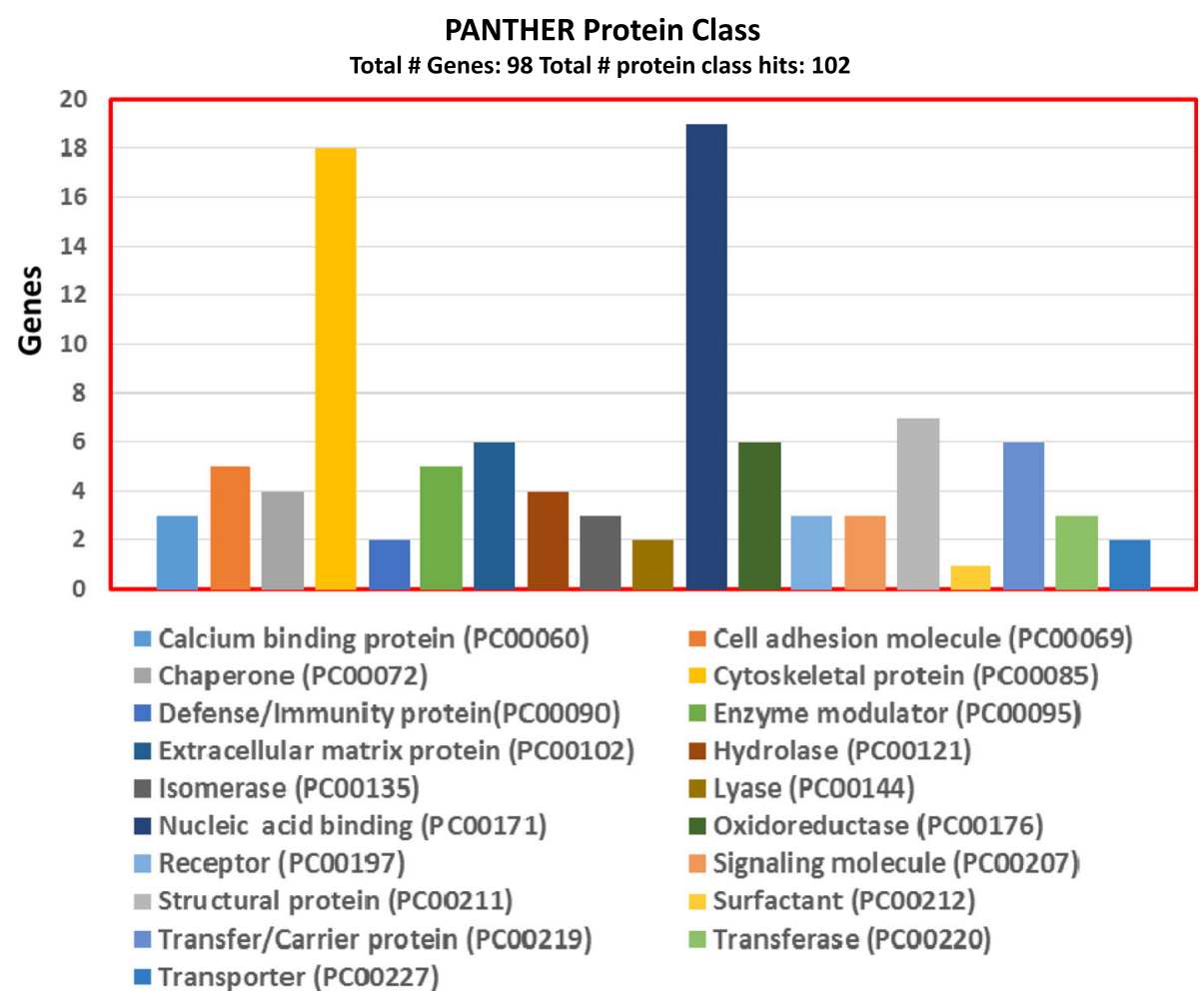

Fig. 2 Functional annotation by protein class of HESM proteins, identified with two or more unique peptides, using Protein Analysis through Evolutionary Relationships (PANTHER) 


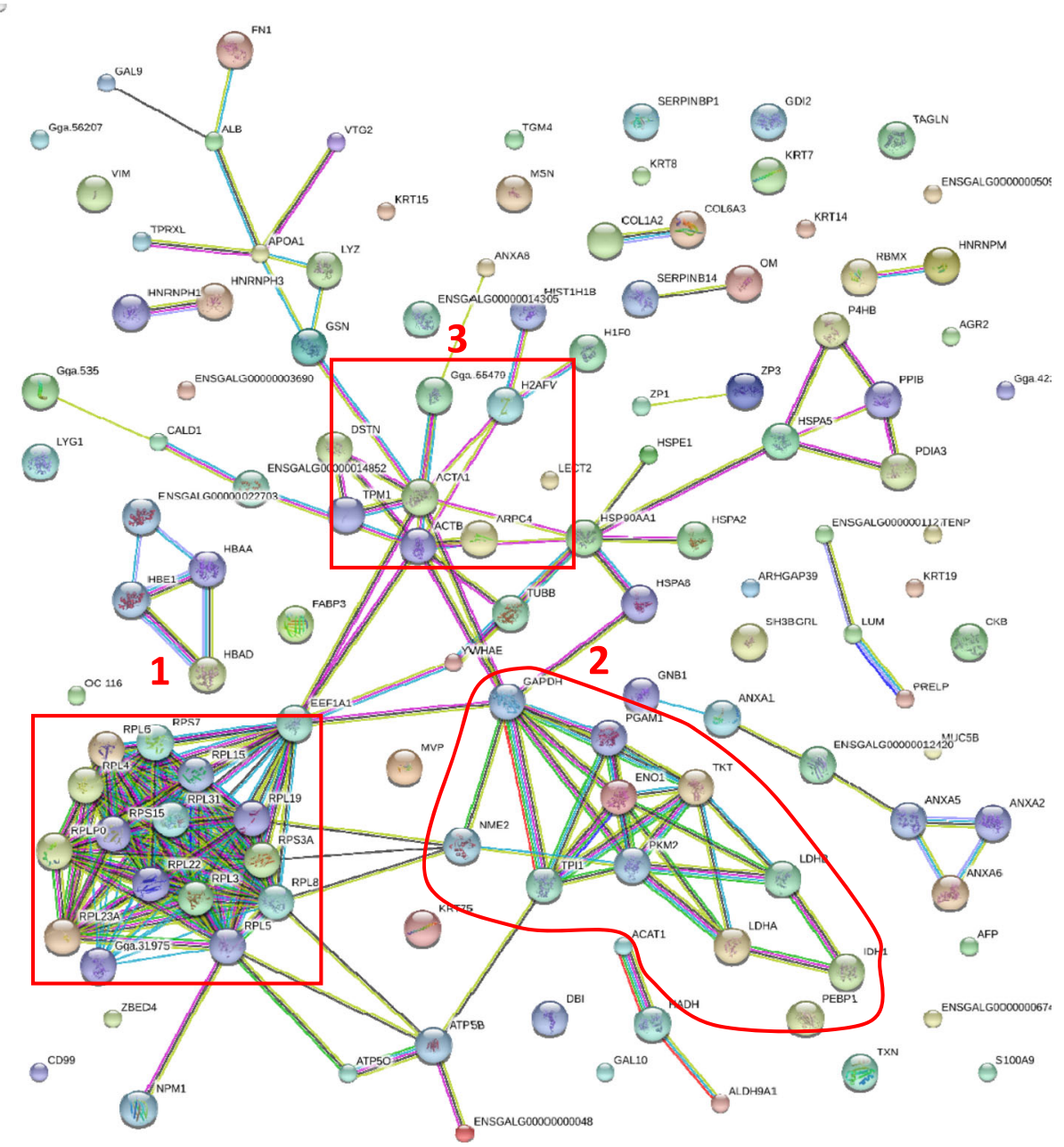

Fig. 3 The protein-protein interaction network of proteins identified with two or more unique peptides. Rectangles showing, 1. Actin node, 2. Ubiquitin node, and 3. Ribosomal and nuclear protein clusters

one unique peptide occurring in replicate sample. The maximum number of bacterial proteins identified belonged to Pseudomonas M10, a family of gram negative bacteria followed by Candidatus, Hyphomonas, and Sphingomonas.

\section{Discussion}

As expected the HESM contained many proteins such as ovalbumin, ovomucoid, ovocleidin-116, and lysozyme that are inherent to egg proteome [8,30-32]. Structural proteins such as keratins, collagens, decorin, lumican, and tropomyosin, and cytoskeletal proteins, such as actin, tubulin, vimentin, and their interacting proteins, were present along with several blood (hemoglobin, $\alpha$ D-globin, annexin, fibronectin) and embryo associated proteins (vitellogenin, zona pellucida sperm-binding proteins, and vitelline membrane outer layer protein). These results are consistent with the reports of Cordeiro and Hincke [32] who showed the occurrence of fibronectin, vitellogenin, and apolipoproteins in the shell membranes of fertilized eggs. The HESM also contained many different enzymes, protease inhibitors, and signaling proteins similar to fresh ESM. However, the HESM seemed to be differentially populated with several proteins associated with glycolysis, carbohydrate, protein, and nucleic acid metabolisms. Many ribosomal, histone, and ribonuclear proteins, and enzymes, associated with protein folding and translocations, were also identified in the HESM extract. However, there was a conspicuous absence of clusterin, a glycoprotein which we and others have found present in the fresh ESM and has been reported as a major component of egg proteome [17, 19, 21, 33-36]. Clusterin is implicated in the maintenance of cellular homeostasis, developmental remodeling, and in the egg, it is correlated with the changes in viscosity of egg white [36-39]. In our previous study with fresh ESM we identified several clusterin peptide fragments in the methanol extract of ESM. However, the absence of any clusterin peptide in HESM under similar extraction 


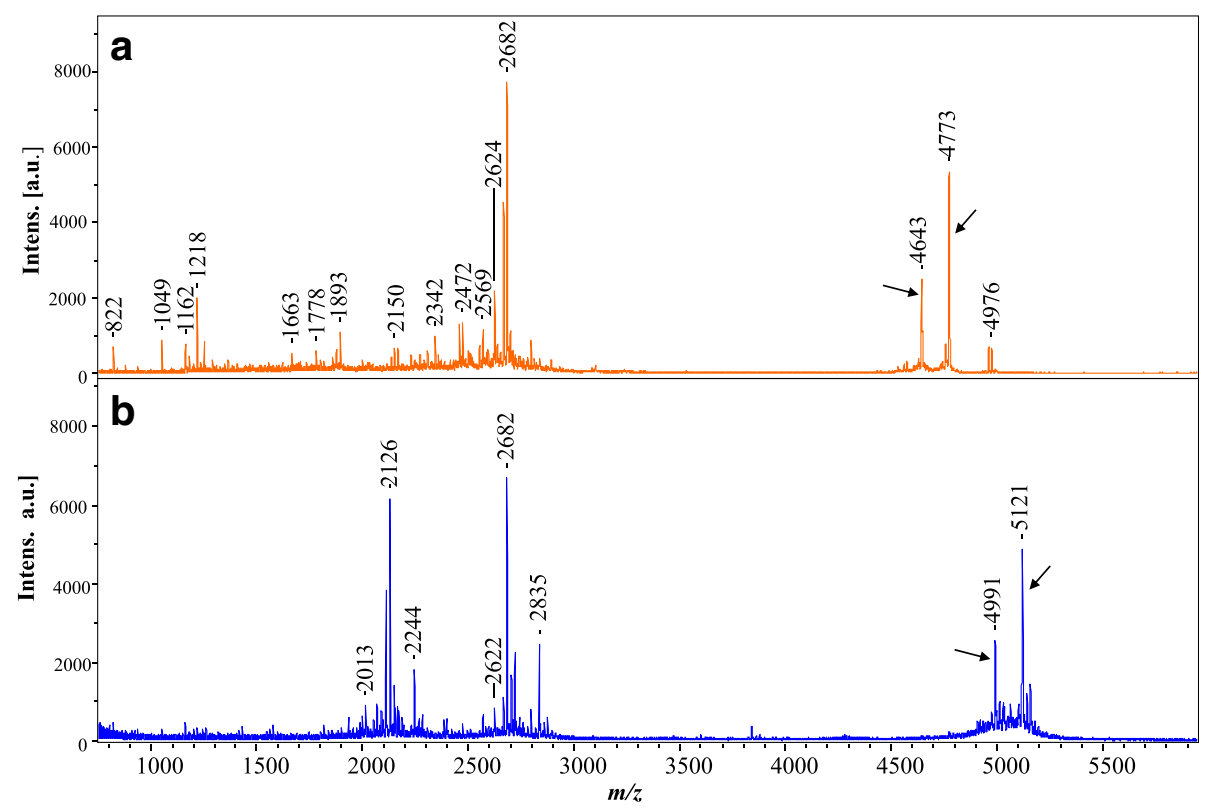

Fig. 4 MALDI-TOF profile of HESM methanol extract before (a) and after reduction and alkylation (b). Two peaks corresponding to $\mathrm{m} / \mathrm{z} 4643 \mathrm{and}$ 4773 (a) show mass shifts by 348 Da corresponding to $\mathrm{m} / \mathrm{z} 4991$ and 5121 (b), respectively (arrows)

condition was intriguing. It is possible that clusterin, in shell membrane, is involved in early embryo development and utilized completely, as the development reaches to its termination. Similarly, there was also a conspicuous absence of gallin, an antimicrobial peptide that occurs uniquely in egg proteome of fresh eggs [17, $33,40]$ whereas two other avian defensins, gallinacin 9 and 10 , were identified along with several other antimicrobial proteins including ovotransferrin, lysozyme, keratin, and ovomucoid. Because the protein profiles of egg undergo qualitative and quantitative changes both, during incubation and passive storage $[21,22,32,38$,
41, 42], the differences in protein profiles of membranes between fresh and hatchery shells appear logical and consistent.

A functional association bioinformatics showed cooccurrence of proteins associated with ubiquitination and apoptosis activities, indicative of large scale protein degradation, expected, with the embryo development and hatching. The other notable protein clusters were carbohydrate and energy metabolizing enzymes (glyceraldehyde phosphate dehydrogenase, $\alpha$-enolase, isocitrate dehydrogenase, aldolase, triose phosphate isomerase) as well as the proteins associated to nucleic acid metabolism, and

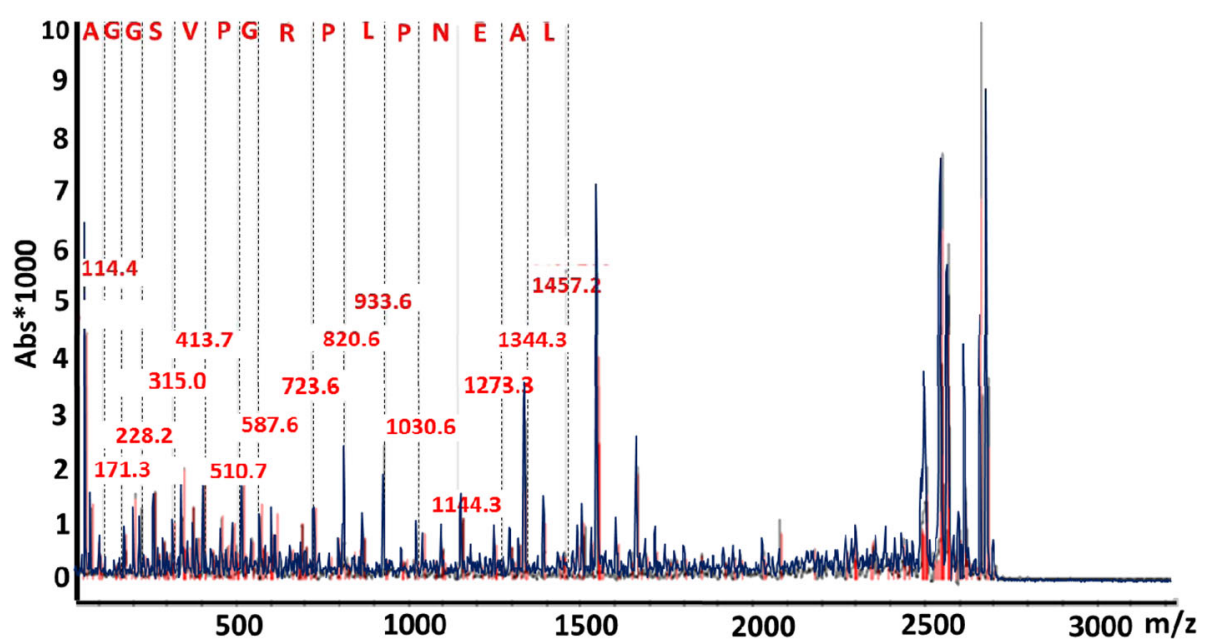

Fig. 5 Fragmentation of $\mathrm{m} / \mathrm{z} 2682$ showing a partial sequence 'AGGSVPGRPLPNEAL' corresponding to Eimeria Apicomplexan specific protein matching by $>92 \%$ identity 
stress protection functions such as heat shock and heat shock cognate proteins (HSP). Besides the endogenous proteins and peptides, the HESM also contained several proteins identified with multi species of both gram positive and gram negative bacteria some belonging to families of phytobacteria, soil bacteria even, marine bacteria. Proteins identified with bacteria such as Candidatus, Enterococci, Yersinia, Butyrivibrio Pseudomonas, Clostridium, and Vibrio are zoonotic that are implicated in human gastrointestinal and respiratory illness including one peptide that belonged to a Eimeria, a protozoa, that causes coccidiosis and enteritis in poultry.

The objective of the study was to gain a better understanding of the potential of egg membrane as an adjuvant that likely provides epigenetic conditioning influencing the post hatch immunity through its proteomic constituents [20]. Based on the above results, it appears that the HESM with its plethora of bioactive proteins, peptides, enzymes, and multi species microbial protein factors, may be a suitable modulator of immunity of post hatch chickens with its muco-adhesive properties and action on gastrointestinal mucosa. Besides, the HESM protein profile also provides a reference to compare and identify similar other allogeneic and xenogeneic sources of material that can improve immunity of post hatch poultry reducing the dependence on antibiotics growth promoters. The identification of diverse bacterial proteins in the HESM makes it appealing since numerous body of evidence has shown that the immunity and disease resistance is greatly influenced by biodiverse factors that include various bacterial and viral antigens [43-45].

\section{Conclusion}

The HESM is a rich source of a variety of bioactive proteins particularly belonging to signaling enzymatic, and regulatory varieties that along with many microbial proteins make it uniquely suitable for use as a modulator to improve post hatch immunity of poultry.

\section{Additional file}

Additional file 1: Table S1. Proteins identified in guanidine $\mathrm{HCL}$ extract of eggshell membranes by LC-MS/MS. Proteins identified with a single peptide are considered "tentatively identified". Table S2. Bacterial proteins identified in Guanidine $\mathrm{HCl}$ extracts of HESM. Proteins identified with one only peptide are considered "tentatively identified". (DOCX 68 $\mathrm{kb})$

\section{Abbreviations}

ACN: Acetonitrile; BCA: Bicinchoninic acid; DTT: Dithiothreitol; ESM: Egg shell membrane; FA: Formic acid; GuHCl: Guanidine hydrochloride; HESM: Hatchery egg shell membrane; IAA: lodoacetamide; LC-MS/MS: Liquid chromatographytandem mass spectrometry; MALDI-TOF: Matrix assisted laser desorption ionization time of flight; MS: Mass spectrometry

\section{Acknowledgment}

We thank Sonia Tsai and Scott Zornes for assistance.

\section{Funding}

This work was carried out as in house project and partly conducted in the State wide Mass spectrometry Facility supported by a grant P30 GM103450 to the University of Arkansas.

\section{Availability of data and materials \\ MS data available.}

\section{Authors' contributions}

NCR and RL conceived and designed the experiments; experiments performed by SKM, RL and NCR; NCR, RL, SKM wrote the manuscript, discussed and approved by NCR, RL, and JL.

\section{Competing interests}

The authors declare that they have no competing interests.

\section{Consent for publication \\ Not applicable.}

\section{Ethics approval and consent to participate}

Not applicable.

\section{Author details}

${ }^{1}$ USDA/Agricultural Research Service, Poultry Production and Product Safety Research Unit, Fayetteville, AR 72701, USA. ${ }^{2}$ Statewide Mass Spectrometry Facility, University of Arkansas, Fayetteville, AR 72701, USA. ${ }^{3}$ Department of Poultry Science, University of Arkansas, Fayetteville, AR 72701, USA.

Received: 22 November 2016 Accepted: 21 February 2017

Published online: 03 March 2017

\section{References}

1. Glatz P, Miao Z, Rodda B. Handling and treatment of poultry hatchery waste: a review. Sustainability. 2011;3:216-37.

2. Cordeiro CM, Hincke MT. Recent patents on eggshell: shell and membrane applications. Recent Pat Food Nutr Agric. 2011;3:1-8.

3. Vlad V, Biova LLC. Eggshell membrane separation method. (USPTO ed., vol. US7954733; 2009.

4. Kovacs-Nolan J, Phillips M, Mine Y. Advances in the value of eggs and egg components for human health. J Agric Food Chem. 2005;53:8421-31.

5. Baláž M. Eggshell membrane biomaterial as a platform for applications in materials science. Acta Biomater. 2014;10:3827-43.

6. King'ori AM. A review of the uses of poultry eggshells and shell membranes Int J Poult Sci. 2011:10:908-12.

7. Miksík I, Eckhardt A, Sedláková P, Mikulikova K. Proteins of insoluble matrix of avian (gallus gallus) eggshell. Connect Tissue Res. 2007:48:1-8.

8. Mikšík I, Ergang P, Pácha J. Proteomic analysis of chicken eggshell cuticle membrane layer. Anal Bioanal Chem. 2014;406:7633-40.

9. Kozuka M, Murao S, Yamane T, Inoue T, Ohkubo I, Ariga H. Rapid and simple purification of lysozyme from the egg shell membrane. J Nutr Sci Vitaminol (Tokyo). 2015;61:101-3.

10. Makkar S, Rath NC, Packialakshmi B, Huff WE, Huff GR. Nutritional effects of egg shell membrane supplements on chicken performance and immunity. Poult Sci. 2015;94:1184-9.

11. Ruff KJ, DeVore DP, Leu MD, Robinson MA. Eggshell membrane: a possible new natural therapeutic for joint and connective tissue disorders. Results from two open-label human clinical studies. Clin Interv Aging. 2009:4:235-40.

12. Ruff KJ, Winkler A, Jackson RW, DeVore DP, Ritz BW. Eggshell membrane in the treatment of pain and stiffness from osteoarthritis of the knee: a randomized, multicenter, double-blind, placebo-controlled clinical study. Clin Rheumatol. 2009;28:907-14.

13. Shi Y, Rupa P, Jiang B, Mine Y. Hydrolysate from eggshell membrane ameliorates intestinal inflammation in mice. Int J Mol Sci. 2014;15:22728-42.

14. Hincke MT, Nys Y, Gautron J. The role of matrix proteins in eggshell formation. Journal of poultry science. 2010;47:208-19. 208-219.

15. Rose ML, Hincke MT. Protein constituents of the eggshell: eggshell-specific matrix proteins. Cell Mol Life Sci. 2009;66:2707-19. 
16. Mann K, Olsen JV, Macek B, Gnad F, Mann M. Identification of new chicken egg proteins by mass spectrometry-based proteomic analysis. World's Poultry Science J. 2008;64:209-18. 209-218.

17. Makkar S, Liyanage R, Kannan L, Packialakshmi B, Lay JO, Rath NC. Chicken egg shell membrane associated proteins and peptides. J Agric Food Chem. 2015:63:9888-98.

18. Ahlborn GJ, Clare DA, Sheldon BW, Kelly RW. Identification of eggshell membrane proteins and purification of ovotransferrin and beta-NAGase from hen egg white. Protein J. 2006;25:71-81.

19. Huopalahti R, López-Fandiño R, Anton M, editors. Bioactive egg compounds. Berlin: Springer; 2007.

20. Makkar SK, Rath NC, Packialakshmi B, Zhou ZY, Huff GR, Donoghue AM. Nutritional supplement of hatchery eggshell membrane improves poultry performance and provides resistance against endotoxin stress. PLOS One. 2016;11, e0159433.

21. Liu Y, Qiu N, Ma M. Comparative proteomic analysis of hen egg white proteins during early phase of embryonic development by combinatorial peptide ligand library and matrix-assisted laser desorption ionization-time of flight. Poult Sci. 2013;92:1897-904.

22. Kaweewong K, Garnjanagoonchorn W, Jirapakkul W, Roytrakul S. Solubilization and identification of hen eggshell membrane proteins during different times of chicken embryo development using the proteomic approach. Protein J. 2013;32:297-308.

23. Kannan L, Liyanage R, Lay Jr J, Packialakshmi B, Anthony N. Identification and structural characterization of avian beta-defensin 2 peptides from pheasant and quail. J Proteomics Bioinform. 2013;6:031-7.

24. Kannan L, Rath NC, Liyanage R, Lay JO. Effect of toll-like receptor activation on thymosin beta-4 production by chicken macrophages. Mol Cell Biochem. 2010;344:55-63.

25. Kannan L, Rath NC, Liyanage R, Lay Jr JO. Evaluation of beta defensin 2 production by chicken heterophils using direct MALDI mass spectrometry. Molec Immunol. 2009;46:3151-6.

26. Schilling B, Rardin MJ, MacLean BX, Zawadzka AM, Frewen BE, Cusack MP, Sorensen DJ, Bereman MS, Jing E, Wu CC, et al. Platform-independent and label-free quantitation of proteomic data using MS1 extracted ion chromatograms in sSkyline: application to protein acetylation and phosphorylation. Mol Cell Proteomics. 2012;11:202-14.

27. D'Souza A, Schilling B, Chytrowski J, MacLean B, Broudy D, Shulman NJ, MacCoss MJ, Gibson BW. MS1Probe-Implementation of a Statistical Tool for MS1-based Quantitation in Skyline for High Throughput Quantitative Analysis. In: Proceedings of the 61st Annual ASMS Conference on Mass Spectrometry \& Allied Topics Minneapolis, MN. 2013.

28. Mi H, Poudel S, Muruganujan A, Casagrande JT, Thomas PD. PANTHER version 10: expanded protein families and functions, and analysis tools. Nucleic Acids Res. 2016;44:D336-42

29. Szklarczyk D, Franceschini A, Wyder S, Forslund K, Heller D, Huerta-Cepas J, Simonovic M, Roth A, Santos A, Tsafou KP, et al. STRING v10: protein-protein interaction networks, integrated over the tree of life. Nucleic Acids Res 2015:43:D447-52.

30. Mann K, Mann M. In-depth analysis of the chicken egg white proteome using an LTQ Orbitrap Velos. Proteome Sci. 2011;9:7.

31. Farinazzo A, Restuccia U, Bachi A, Guerrier L, Fortis F, Boschetti E, Fasoli E, Citterio A, Righetti PG. Chicken egg yolk cytoplasmic proteome, mined via combinatorial peptide ligand libraries. J of Chromatography A. 2009; 1216:1241-52.

32. Cordeiro CM, Hincke MT. Quantitative proteomics analysis of eggshell membrane proteins during chick embryonic development. J Proteomics. 2016;130:11-25

33. Mann K. The chicken egg white proteome. Proteomics. 2007;7:3558-68.

34. Guérin-Dubiard C, Pasco M, Mollé D, Désert C, Croguennec T, Nau F. Proteomic analysis of hen egg white. J Agric Food Chem. 2006;54:3901-10.

35. Mann K, Gautron J, Nys Y, McKee MD, Bajari T, Schneider WJ, Hincke MT. Disulfide-linked heterodimeric clusterin is a component of the chicken eggshell matrix and egg white. Matrix Biol. 2003;22:397-407.

36. Wang J, Wu J. Proteomic analysis of fertilized egg white during early incubation. EuPA Open Proteom. 2014;2:38-59.

37. Jones SE, Jomary C. Clusterin. Int J Biochem Cell Biol. 2002;34:427-31.

38. Omana DA, Liang Y, Kav NN, Wu J. Proteomic analysis of egg white proteins during storage. Proteomics. 2011;11:144-53.

39. Rohne P, Prochnow H, Koch-Brandt C. The CLU-files: disentanglement of a mystery. Biomol Concepts. 2016;1:1-15.
40. Gong D, Wilson PW, Bain MM, McDade K, Kalina J, Herve-Grepinet V, Nys Y, Dunn IC. Gallin; an antimicrobial peptide member of a new avian defensin family, the ovodefensins, has been subject to recent gene duplication. BMC Immunol. 2010;11:12.

41. Qiu N, Ma M, Zhao L, Liu W, Li Y, Mine Y. Comparative proteomic analysis of egg white proteins under various storage temperatures. J Agric Food Chem. 2012;60:7746-53.

42. Qiu N, Liu W, Ma M, Zhao L, Li Y. Differences between fertilized and unfertilized chicken egg white proteins revealed by 2-dimensional gel electrophoresis-based proteomic analysis. Poult Sci. 2013;92:782-6.

43. Pi C, Allott EH, Ren D, Poulton S, Lee SY, Perkins S, Everett ML, Holzknecht ZE, Lin SS, Parker W. Increased biodiversity in the environment improves the humoral response of rats. PLoS One. 2015;10, e0120255.

44. Hanson MA, Gluckman PD. Early developmental conditioning of later health and disease: physiology or pathophysiology? Physiol Rev. 2014;94:1027-76.

45. Morris JA, Harrison LM, Lauder RM, Telford DR, Neary R. Low dose, early mucosal exposure will minimize the risk of microbial disease. Med Hypotheses. 2012;79:630-4

\section{Submit your next manuscript to BioMed Central and we will help you at every step:}

- We accept pre-submission inquiries

- Our selector tool helps you to find the most relevant journal

- We provide round the clock customer support

- Convenient online submission

- Thorough peer review

- Inclusion in PubMed and all major indexing services

- Maximum visibility for your research

Submit your manuscript at www.biomedcentral.com/submit

) Biomed Central 